\title{
Pockmark formation and activity, U.K. block 15/25, North Sea
}

\author{
ALAN JUDD, DAVID LONG \& MICHAEL SANKEY
}

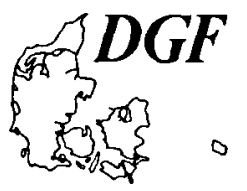

\begin{abstract}
Judd, A. Long, D. \& Sankey, M.: Pockmark formation and activity, U.K. block 15/25, North Sea. Bulletin of the Geological Society of Denmark, vol. 41, pp. 34-49, Copenhagen, 1994-03-30. https://doi.org/10.37570/bgsd-1995-41-04
\end{abstract}

\begin{abstract}
Digital seismic reflection (boomer) profiles of an active pockmark, in UK block 15/25, North Sea, reveal that the feature was formed prior to the deposition of the most recent sediments, probably by vigorous (or even catastrophic) gas escape. This release may have been triggered by the melting of ground ice when North Atlantic waters first entered the North Sea after the last glaciation, about 13,000 years ago. Possible sources of the gas are investigated by examining the composite log from a nearby petroleum exploration well; it is concluded that, although the gas may originate from the Kimmeridge Clay, it probably comes from lignites of Tertiary age. Its migration towards the seabed is interrupted by local accumulations at several horizons, the shallowest of which ( $<80 \mathrm{~m}$ below seabed) is trapped beneath clayey sediments of the Coal Pit Formation. The topography of the base of this layer apparently controls the location of gas migration pathways to the seabed. As these lead to pockmarks which formed long ago, and as these pockmarks are still active today, it is probable that the migration pathways have remained throughout the intervening period. Gas accumulating beneath the Coal Pit Formation may migrate laterally to reach the pathways.
\end{abstract}

Alan Judd, School of the Environment, University of Sunderland, Benedict Building, St. George's Way, Sunderland, SR2 7BW, U.K.. David Long and Michael Sankey, British Geological Survey, Murchison House, West Mains Road, Edinburgh, EH9 3LA, U.K. October 25th, 1992.

\section{Introduction}

Pockmarks, seabed depressions caused by the escape of fluids through the seabed, are present over much of the northern North Sea (Hovland \& Judd 1988). In 1983, during a routine site survey of a site in U.K. block $15 / 25 \mathrm{~b}$, North Sea, an anomalously large pockmark with active gas seepage was discovered. The pockmark is over 450 metres across and 18 metres deep, and was first described by Hovland \& Sommerville (1985). Subsequent study of this pockmark has confirmed the presence of active gas seeps and has revealed methane-derived carbonates and a benthic fauna which is atypical of the area. (Hovland \& Judd 1988; Dando, Austen, Burke, Kendall, Kennicutt, Judd, Moore, O'Hara, Schmaljohann \& Southward 1991). Evidence of shallow gas occurs extensively over the survey area, and at various depths below seabed. This paper addresses the origin, distribution and migration of the gas, and considers mechanisms for the formation of the pockmarks.

The data described here were collected during an ongoing programme of research into this, and other nearby active pockmarks, from previous geophysical surveys and from a released composite log of a petroleum exploration well (15/25b-la).

\section{Location and previous work}

The survey area (see Fig. 1) is located in U.K. block $15 / 25 \mathrm{~b}$ in the north-central North Sea. It comprises an area covered by the site survey undertaken prior to the drilling of petroleum exploration well $15 / 25 \mathrm{~b}-1 \mathrm{a}$, and a larger area surveyed in 1990 and 1991. It lies where the general water depth is about 150 metres, near the centre of the Witch Ground Basin; a large topographic basin partially infilled by sediments of the Witch Ground Formation. These are soft, mainly glaciomarine clays and silts of late Quaternary age (Stoker, Long \& Fyfe 1985). The seabed is characteristically pockmarked; the average pockmark density in this area being 10 to $30 \mathrm{~km}^{-2}$ (Long 1986). Most of these pockmarks are $<100$ metres across and about 2-3 metres deep. Within the survey area there are three large pockmarks which are actively seeping gas. For reference purposes they are referred to by name, the names being those of survey ships used in the area (see Fig. 1). 'Scanner' and the smaller 'Scotia' were discovered during the 1983 site survey. Their presence and seepage activity has been confirmed by subsequent surveys in 1985, 1988, 1989, 1990 and 1991. 'Challenger', which lies some three kilometres to the north-north-west, was surveyed during 1990 and revisited in 1991 (it had

Bulletin of the Geological Society of Denmark 
also been discovered in 1981 during regional surveys conducted by the British Geological Survey).

'Scanner' and 'Challenger' are of similar size and depth; 'Scotia' is considerably smaller, yet it is still anomalously large and deep when compared to most pockmarks in the area. It is known that there are other anomalously large and (probably) active pockmarks in this part of the North Sea, however they are thought to be few and far between. There have been no published reports of other active pockmarks in the North Sea.

\section{Geophysical data acquisition and processing}

The data utilised for this study includes:

1) interpreted analogue and digital seismic reflection data from the 1983 site survey (undertaken by Geoteam (UK) Ltd. for Conoco U.K. Ltd.); Decca Pulse-8 was used for position fixing. Analogue seismic data were acquired using a Nova Scotia Research Foundation Deep-Tow Sparker, operating at 300 joules, with a firing rate of $0.25 \mathrm{~s}$. Digital data were acquired using a 9-element E. G. \& G. sparker source operated at 14 kjoules and fired at approximately 6 second intervals to give a $12.5 \mathrm{~m}$ shot spacing. The return signal was received by a Geco streamer with 4812.5 m-long hydrophone groups, and was recorded by a DFS V digital recording system (Geoteam 1983).

2) digital seismic reflection data from a survey undertaken in 1991 by Marconi UDI Ltd. for Conoco U.K. Ltd.; The seismic source used was a $4 \times 40 \mathrm{cu}$. in. sleeve gun array, fired at $6.25 \mathrm{~m}$ intervals. A $600 \mathrm{~m}$. hydrophone with $4812.5 \mathrm{~m}$-long groups received the signal, which was recorded by an E.G. \& G. 2420 recorder. A MicroMax was used for on-board processing to produce brute stacks (see Fig. 2). Position fixing was achieved with a Star-Track differential global positioning system (Marconi UDI Ltd., 1991). Full post-processing, to then current industry standards, was undertaken on data from each of the above surveys.

3) digital shallow seismic data acquired from the N.E.R.C. ship RRS Challenger, during 1990 and 1991. Position fixing was by Global Position System. Seismic profiling was undertaken with a BGS-modified Huntec Deep-Towed Boomer operating at a depth of $90 \mathrm{~m}$, about $60 \mathrm{~m}$ above the seabed. A firing rate of 0.7 seconds was used, which, with a towing speed of 4 knots gave a shot interval of $1.4 \mathrm{~m}$. The analogue data were displayed on a Waverley TLR recorder with a swell filter, $800 \mathrm{~Hz}-2 \mathrm{kHz}$ bandpass filter and a linear gain applied.

The digital data were recorded in SEGY format on 0.5" magnetic tape with a sample rate of $12.5 \mathrm{kHz}$ and a trace length of $240 \mathrm{~ms}$. A bandpass filter of $142 \mathrm{~Hz}$ to $4.58 \mathrm{kHz}$ was applied prior to sampling. The towfish depth was recorded in the trace headers so that the data could be compensated for long-term vertical towfish movement.

The digital data were subsequently processed using the SKS seismic processing package at the British Geological Survey. The two main objectives of the processing were to compress the wavelet in order to improve the resolution of the fine layering, and to apply an accurate swell filter to improve the continuity of events. Wavelet compression was achieved by the use of signature deconvolution and variant filtering. The signature of the deconvolution was extracted from the averaged seabed return. It was found that the frequency content of the records varies too rapidly along the trace to allow statistical deconvolution to be successful. The digital swell filter, which uses traces on either side of the trace being processed, was found to be more accurate than the analogue swell filter which can only be used on the previous traces. An exponential gain function and a correction for the depth of the towfish were also applied.

As a result of the digital processing, features seen on the analogue recordings of the data can be seen with far greater clarity, and previously unseen detail has been revealed. The digital boomer profile presented as Fig. 3 is a North-South section across the 'Scanner' pockmark.

\section{Composite log of well $15 / 25 b-1 a$}

Well 15/25b-1a was drilled by Conoco (UK) Ltd in 1984. The released composite log includes lithostratigraphic information which is summarised in Fig. 4 (the topmost section of which is derived from geophysical data presented in this paper).

\section{Geological setting}

Block 15/25 lies within the Witch Ground Graben, a major structural feature which developed between Triassic and early Cretaceous times. The basin was a major centre of deposition during the late Jurassic and early Cretaceous, and it has been infilled subsequently by a thick sequence of Tertiary and Quaternary sediments (Andrews, Long, Richards, Thomson, Brown, Chesher \& McCormac 1990). The exploration well revealed only a thin sequence of Mesozoic sediments lying unconformably on the Lower Carboniferous (Tournasian - see Fig. 4). This suggests that the site overlies a structural high within the graben. The Tertiary succession comprises a thick (approx. $2000 \mathrm{~m}$ ) succession dominated by clays, but includes sandstone and limestone beds. Lignite is present within some horizons of the Hordaland and Nordland sediments.

During the Quaternary, the Witch Ground Basin was a site of net deposition, with the deposition of between 350 and $400 \mathrm{~m}$ of sediment in the $15 / 25$ area. Although there is local evidence of glacial conditions within the marine deposits of the early Pleistocene (Stoker \& Bent 1987), 

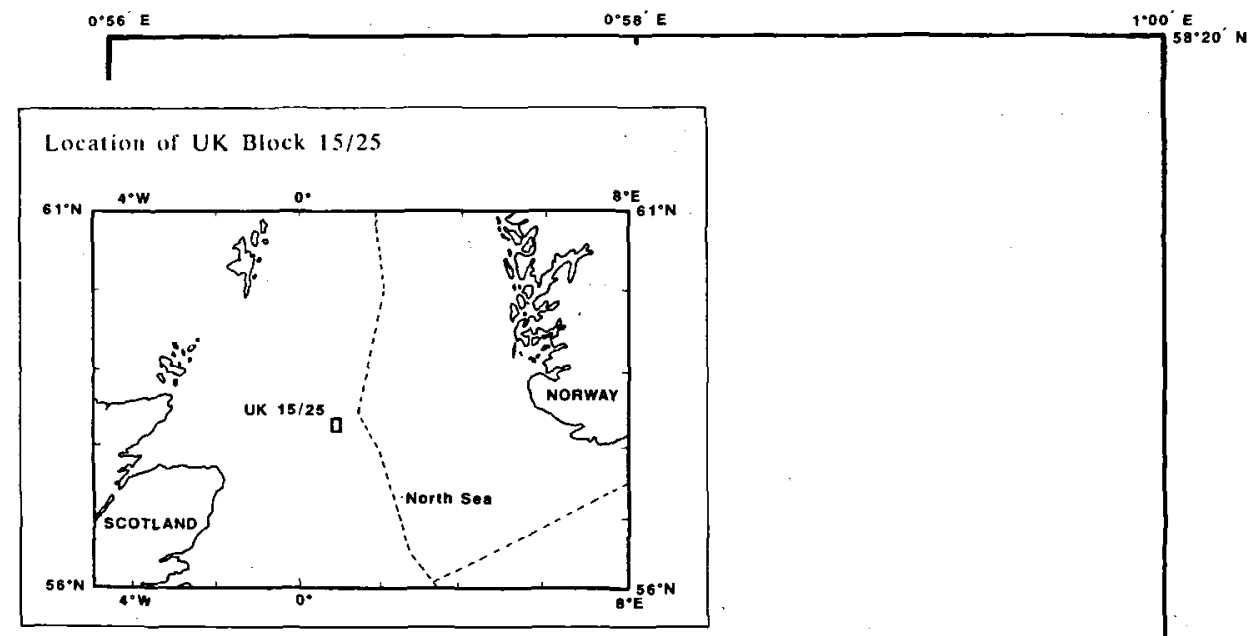

Fig. 1. Location map, UK 15/25

seepage area.

Showing the three pockmarks:

'Scanned', 'Scotia' and 'Challenger', and the location of petroleum

exploration well 15/25b-1a.

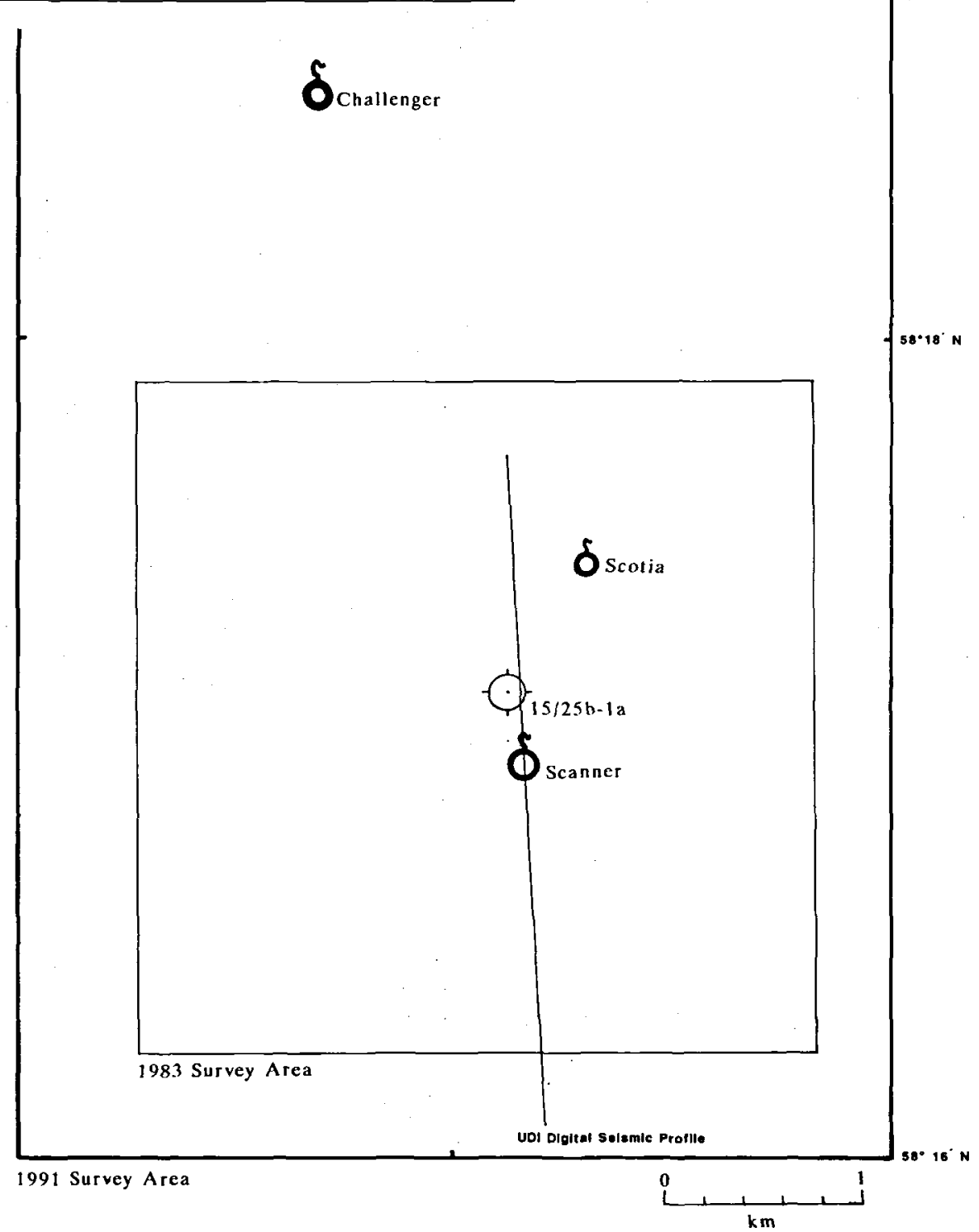




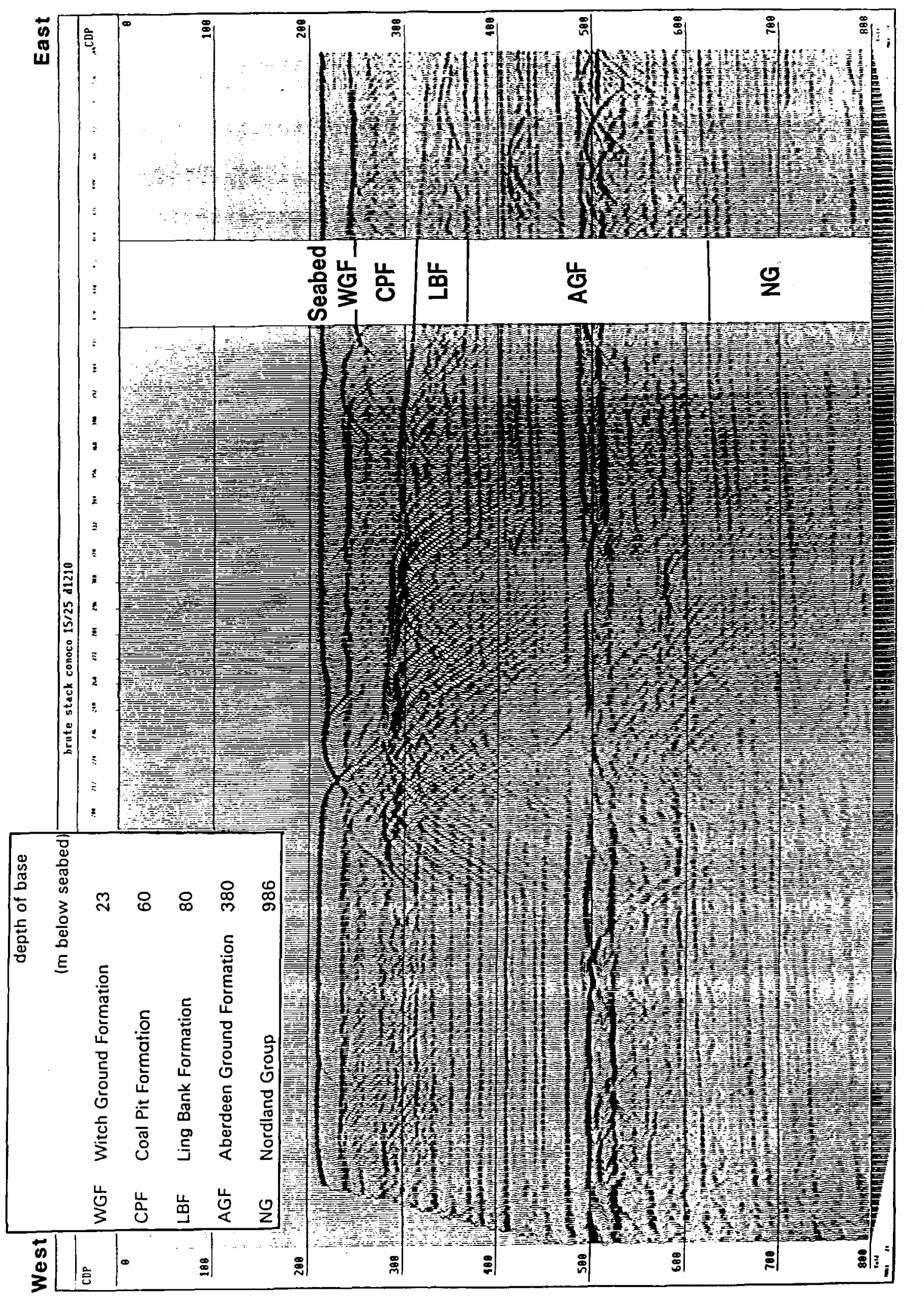

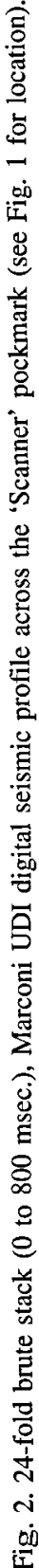

Judd et al.: Pockmark formation and activity 


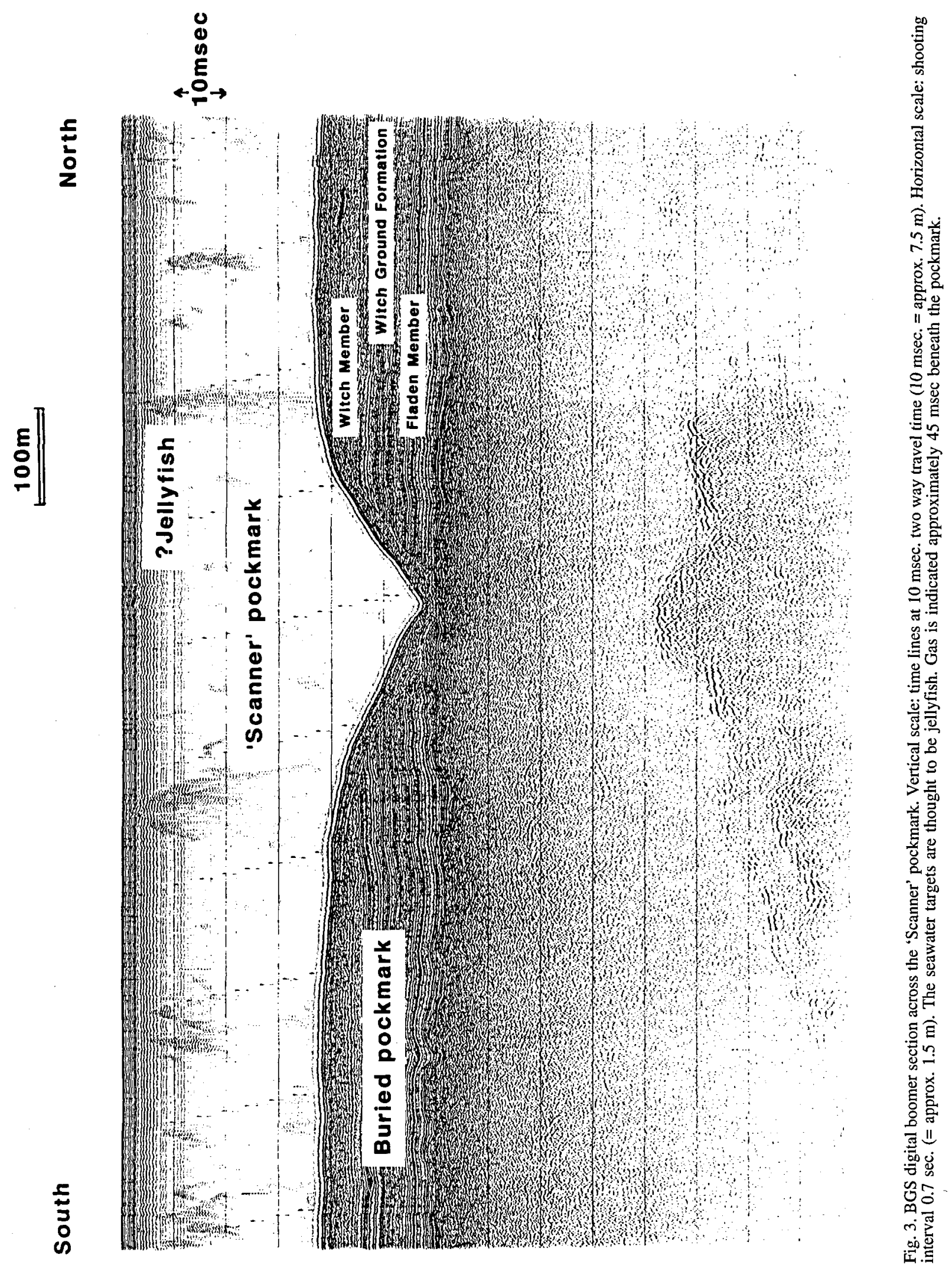




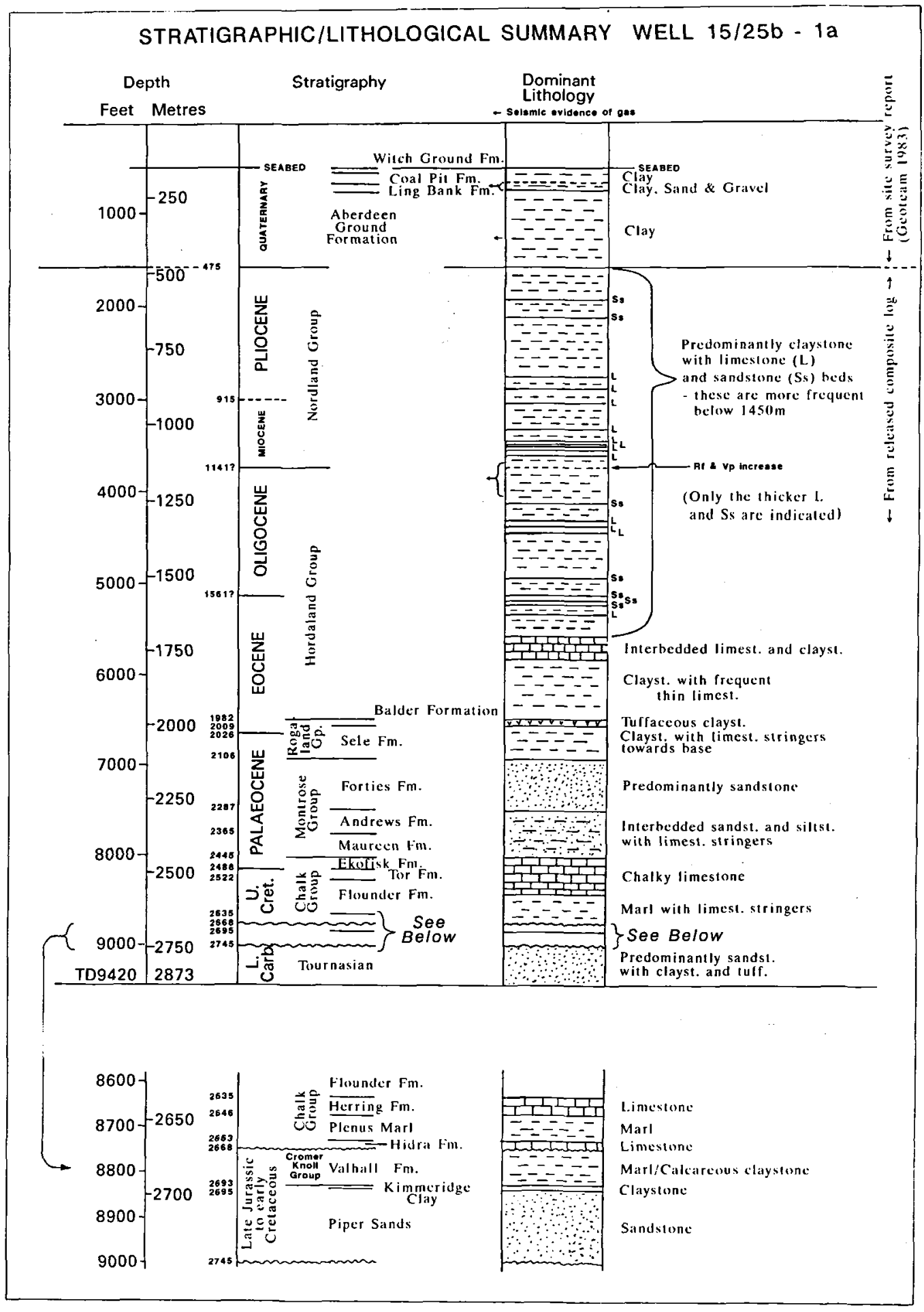

Fig. 4. Stratigraphic/lithological summary of well 15/25b-1a. Compiled from the Composite Log and shallow seismic profiles. 


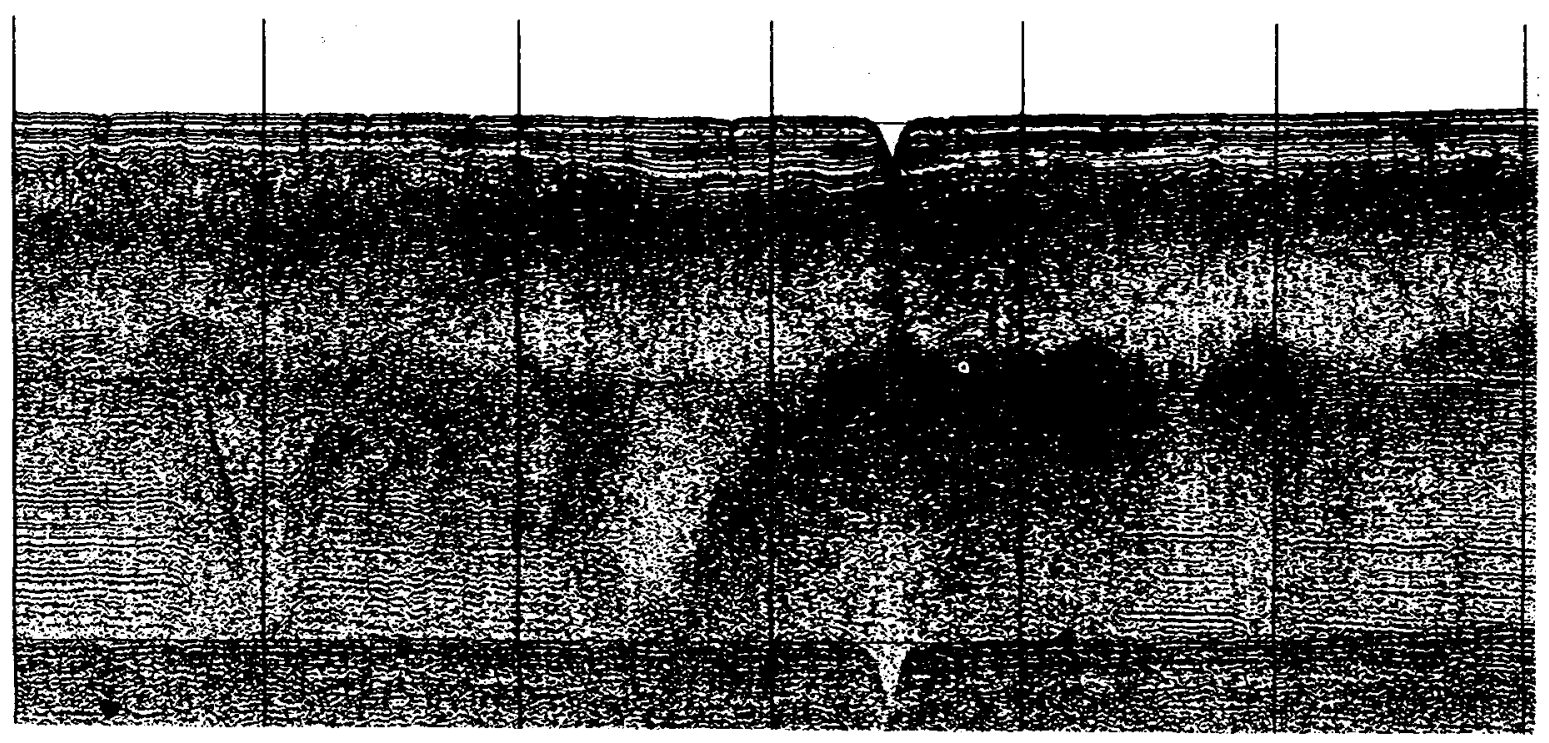

Fig. 5a. BGS sparker profile across the 'Challenger' pockmark (after Andrews et al., 1990).

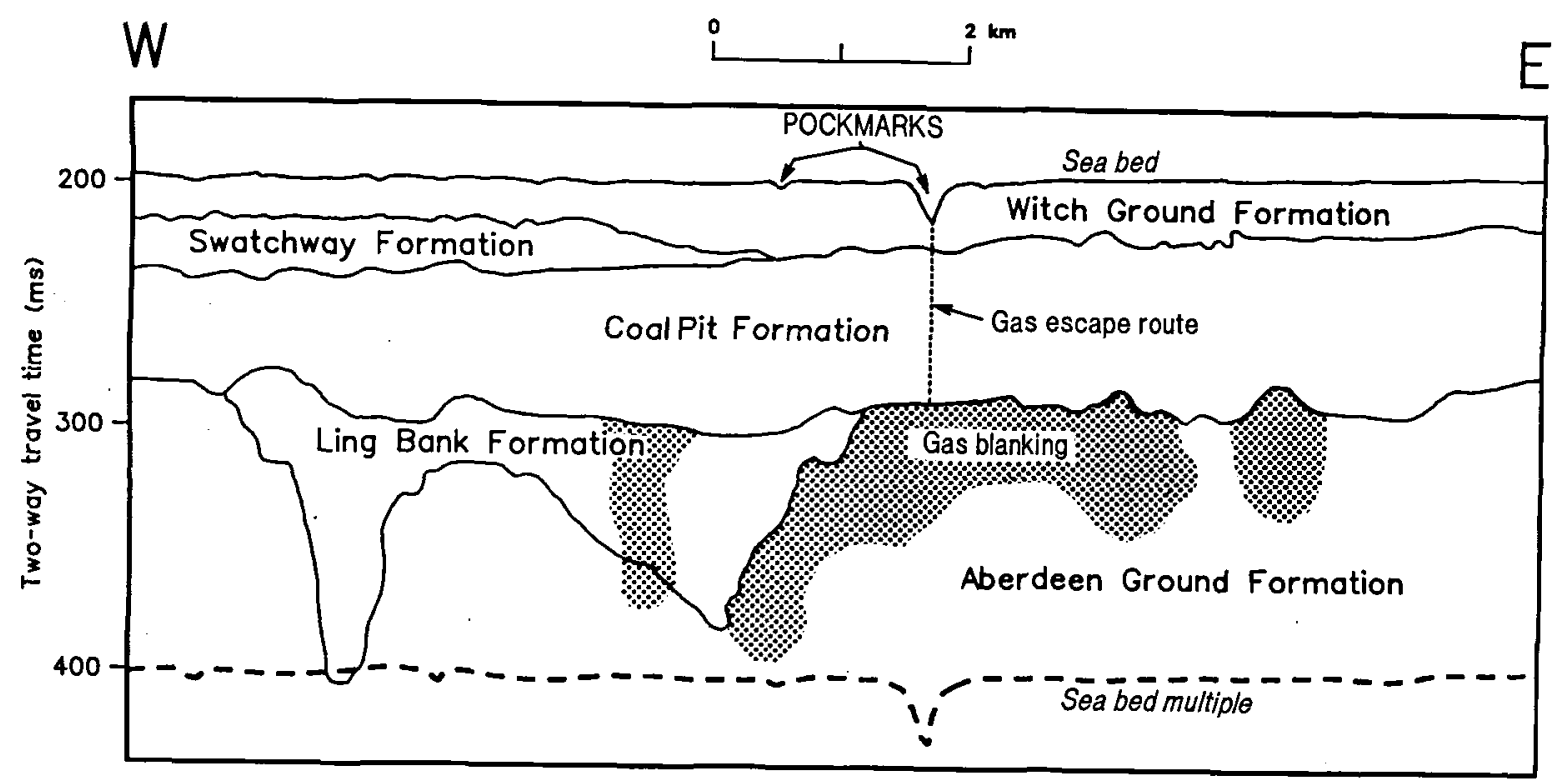

Fig. 5b. Interpretation of $5 \mathrm{a}$.

the onset of major glacial conditions approximately 750,000 years ago is represented by a change from acoustically well-layered sediments to a chaotic zone of incoherent reflections at the top of the Aberdeen Ground Formation. The overlying seismostratigraphic units, including the Ling Bank and Fisher Formations, illustrate a series of erosive episodes with contrasting lithologies. These represent glacial conditions of the Middle and Late Pleistocene. The upper seismostratigraphic units consist of the Coal Pit, Swatchway and Witch Ground Forma- tions. The Coal Pit Formation comprises firm to hard dark grey to brownish-grey, muddy, pebbly sands or sandy muds with rare shell fragments, believed to have been deposited during the glacial-interglacial-glacial cycle from the Saalian to the Weichselian (Stoker et al. 1985). The Swatchway Formation usually comprises silty sandy clays with rare pebbles, and it often has a reversed shear strength profile (Stoker et al. 1985). It is interpreted as a reworked proximal glaciomarine deposit (Andrews et al. 1990). It is absent from the $15 / 25$ site, its subcrop 


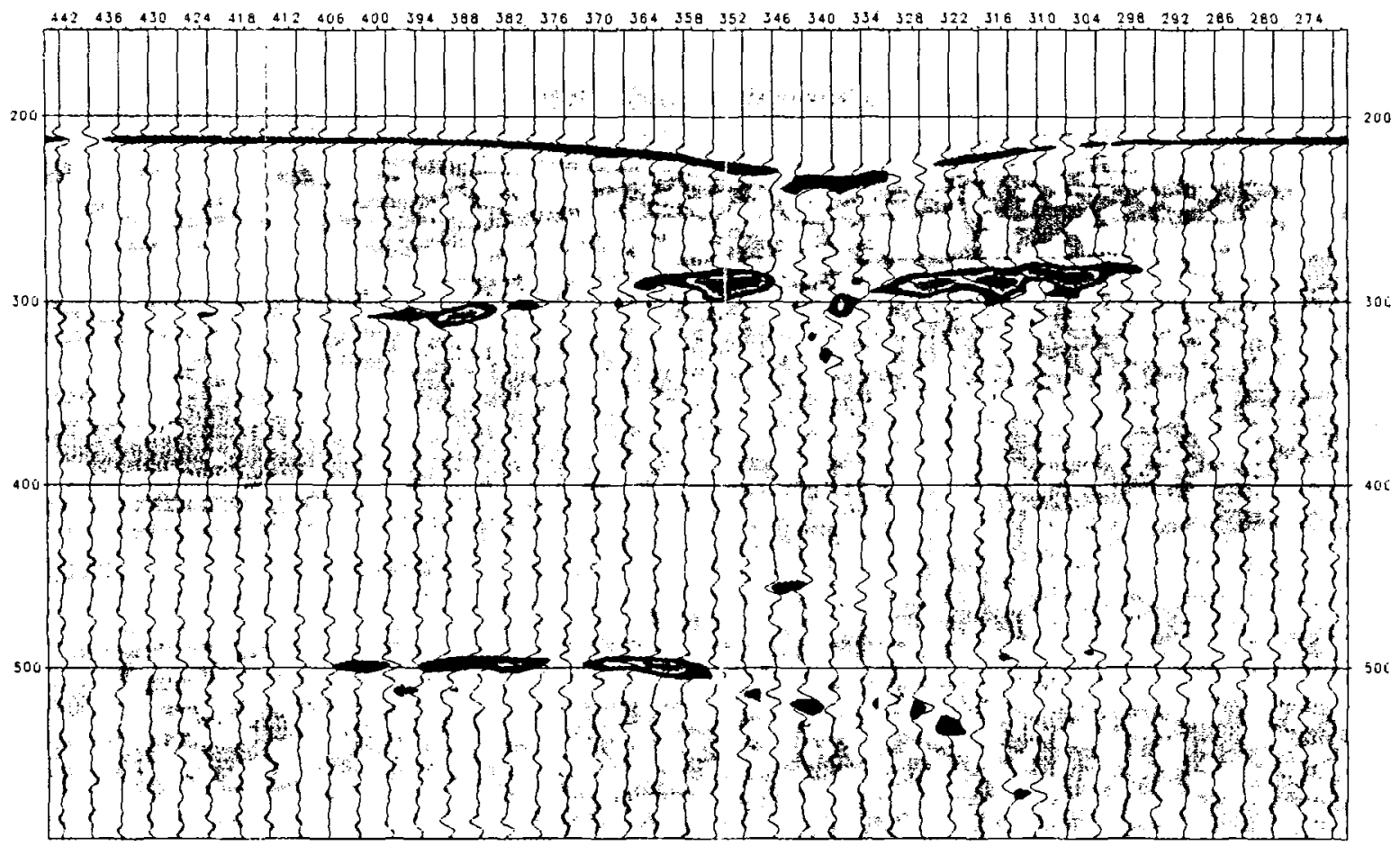

Fig. 6. Attribute analysis of Marconi UDI digital profile across the 'Scanner' pockmark (as shown in Fig. 2) showing reflection strength (original in colour).

terminating a short distance away (see Fig. 5). The Witch Ground Formation comprises very soft to soft, greenishgrey to greyish-brown clays and silts with subordinate sandy horizons and rare small pebbles in the lower part of the sequence. It is interpreted as a glaciomarine deposit of late Weichselian to Holocene age (Stoker et al. 1985). The Witch Ground Formation has been subdivided into three members, the Witch, Fladen and Glenn Members, which represent differing environmental conditions (Andrews et al. 1990). The Quaternary stratigraphy is indicated in Figs. 2, 3 and 5.

\section{Late- to post-glacial history}

The environmental history of the area, and the pockmark site in particular, has been controlled by climatic changes since the last glacial maximum about 18,000 years ago. Before 15,000 years ago, the area was probably a shallow sea with a near permanent sea-ice cover. This, together with small icebergs, transported sediment to the area. The seabed was continually being re-worked by the ice keels, and locally, ice loading caused overconsolidation of the underlying sediments. During periods of low temperature it is likely that permafrost occurred, creating lenses of ground ice extending from adjacent land areas.

As the temperature began to rise, about 15,000 years ago, sea level rose slightly, the sea ice became thinner, and the seabed ceased to be disturbed by the ice keels. This transition is represented by the irregular base of the Witch Ground Formation where the last sea ice plough marks are preserved (Stoker \& Long 1984). Between about 15,000 and 13,000 years ago, rapid sedimentation beneath a cover of sea ice took place, forming the acoustically well-layered Fladen Formation (Long, Bent, Harland, Gregory, Graham \& Morton 1986, Long 1992).

About 13,000 years ago, the cold polar front was moving rapidly northwards past Britain, permitting the entry of warmer North Atlantic waters into the North Sea. Palæontological evidence (Long et al. 1986) suggests a rapid rise in temperature with only limited sea ice. Such a rise in bottom water temperatures is also likely to have rapidly melted any sub-surface lenses of ground ice.

After 13,000 years ago, marine sedimentation continued, with the short-term return of sea ice during the Younger Dryas (Loch Lomond) period (circa 11,000 to 10,000 years ago; Long et al. 1986). Radiocarbon dating of seabed sediments in the Witch Ground Basin suggest that there has been virtually no sediment input since the early Holocene, about 8,000 years ago (Erlenkeuser 1979 \& pers. comm. 1988, Johnson \& Elkins 1979). Sedimentation today is restricted to the formation of the Glenn Member through re-working of the Witch Member during pockmark formation. Gas escape during pockmark formation sorts the near-surface sediment in such a way that a very thin layer of very well-sorted silt forms, 


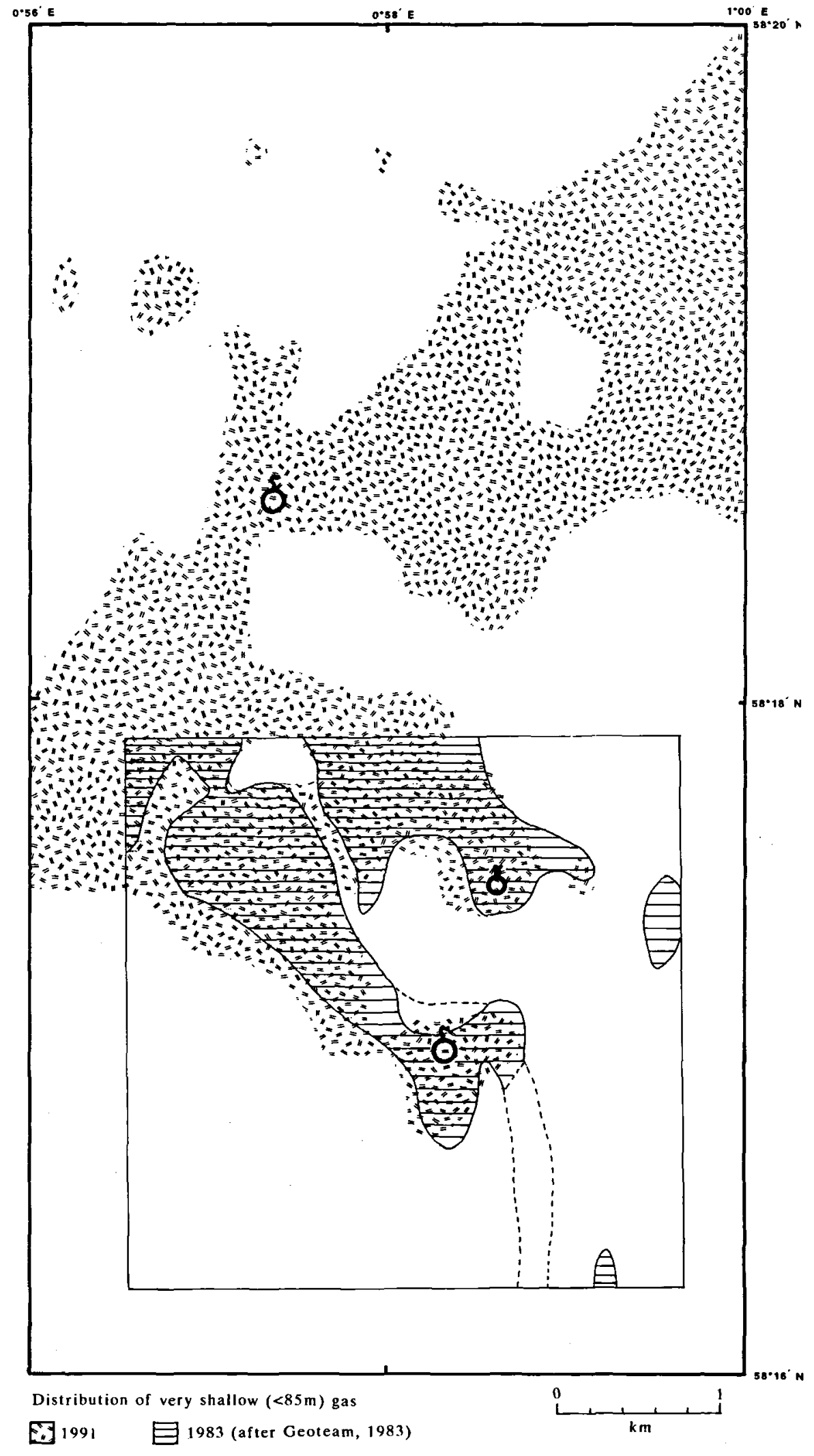

Fig. 7. Distribution of very shallow gas, i.e. gas trapped beneath the Coal Pit Formation, as indicated from the Geoteam survey (1983) and the Challenger survey (1991). 


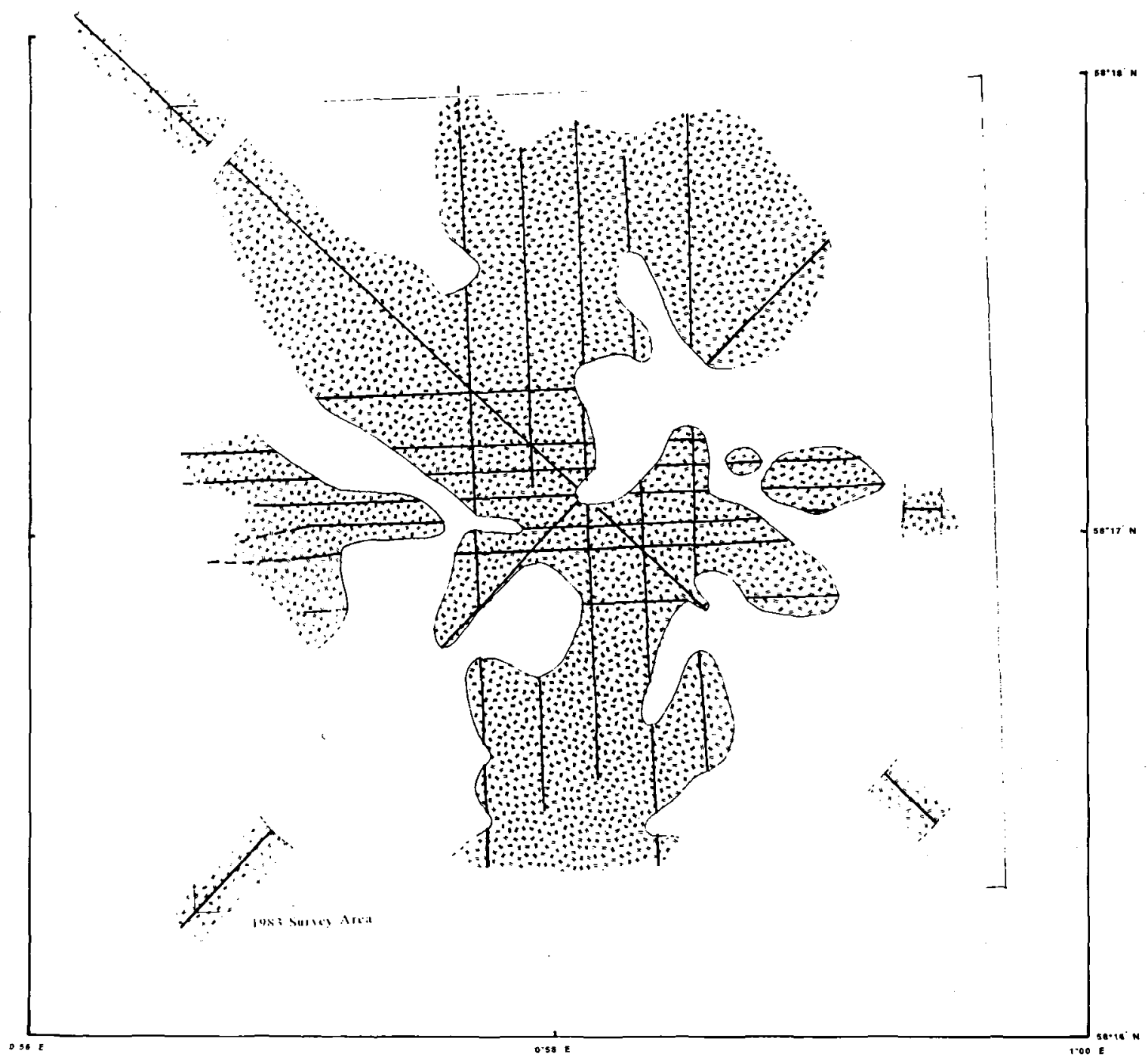

Fig. 8. Extent of bright spots (shallow gas) within the Aberdeen Ground Formation 230-250 m below seabed (after Geoteam, 1983). Bars - bright spots; ornament - probable extent of gas.

thickening into individual pockmarks (Stoker et al. 1985, Andrews et al. 1990).

\section{Occurrences of shallow gas}

Evidence interpreted as being indicative of shallow gas is present in the data produced by each of the seismic surveys. This includes acoustic features such as bright spots (see example in Fig. 2) and acoustic turbidity as well as secondary evidence in the form of pockmarks, buried pockmarks etc. (see Fig. 3). Whereas none of this evidence represents conclusive proof of the presence of gas, two factors indicate that the interpretation is correct. Firstly, work undertaken on the 'Scanner' pockmark in- cludes visual observations, and collection of gas bubbles (see Hovland \& Judd 1988, Dando pers. comm). Secondly, attribute analyses (analysis of reflection strength, amplitude, instantaneous phase etc.) applied to the digital seismic data acquired by Marconi UDI Ltd., have demonstrated that many of the features characteristic of gascharged sediments (see Walker 1990) are present (an example is shown in Fig. 6). It is therefore concluded that gas is indeed present at the several depths below seabed indicated by the seismic evidence.

From the seismic evidence it is apparent that gas accumulations are present at the following depths:

1) < $100 \mathrm{~m}$ : gas within the Ling Bank Formation and at the top of the Aberdeen Ground Formation is trapped 


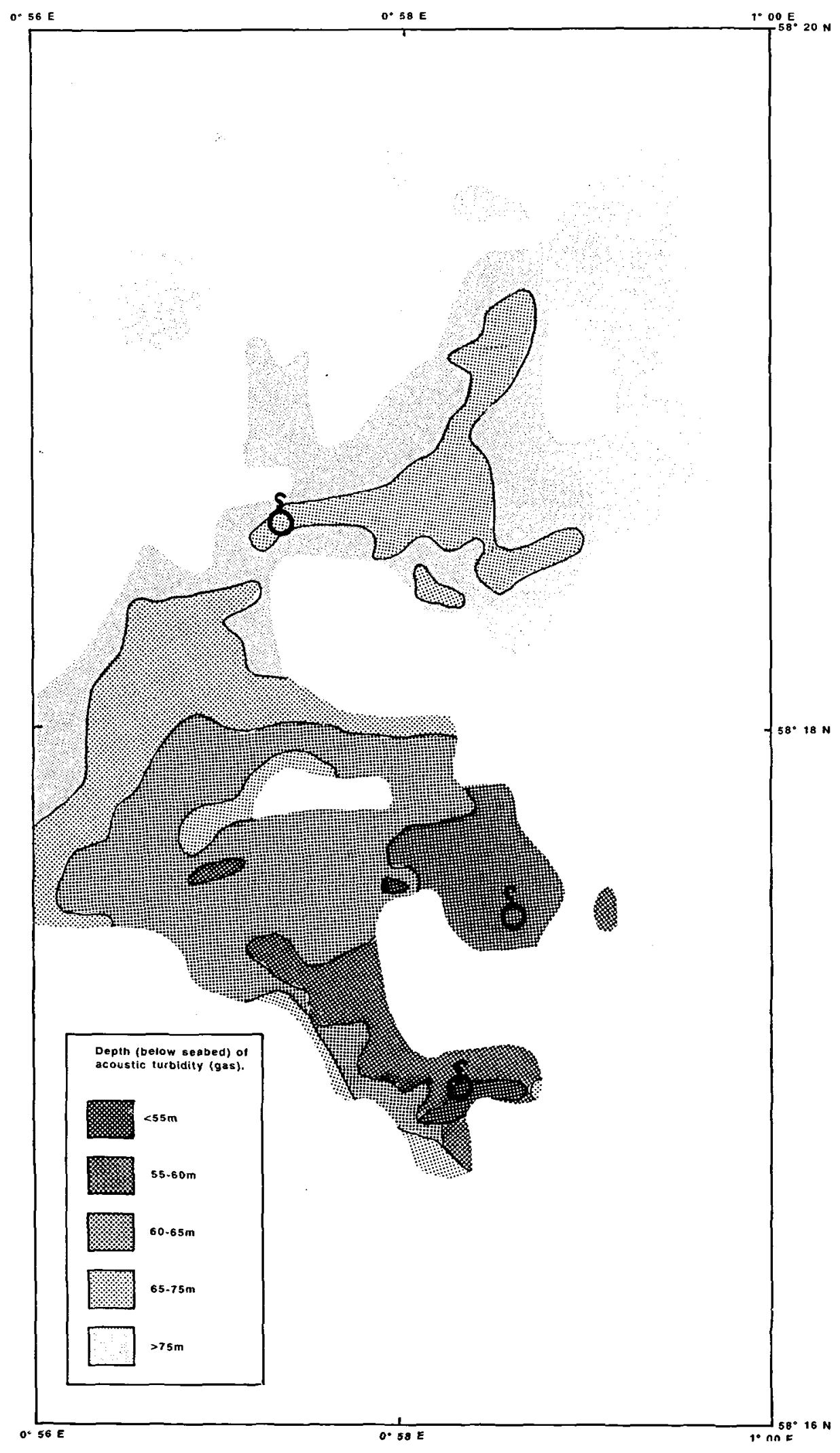

Fig. 9. Depth of top of shallow gas

trapped beneath the Coal Pit Formation (as mapped from the Challenger 1991

data). Un-ornamented areas are gas-free. 


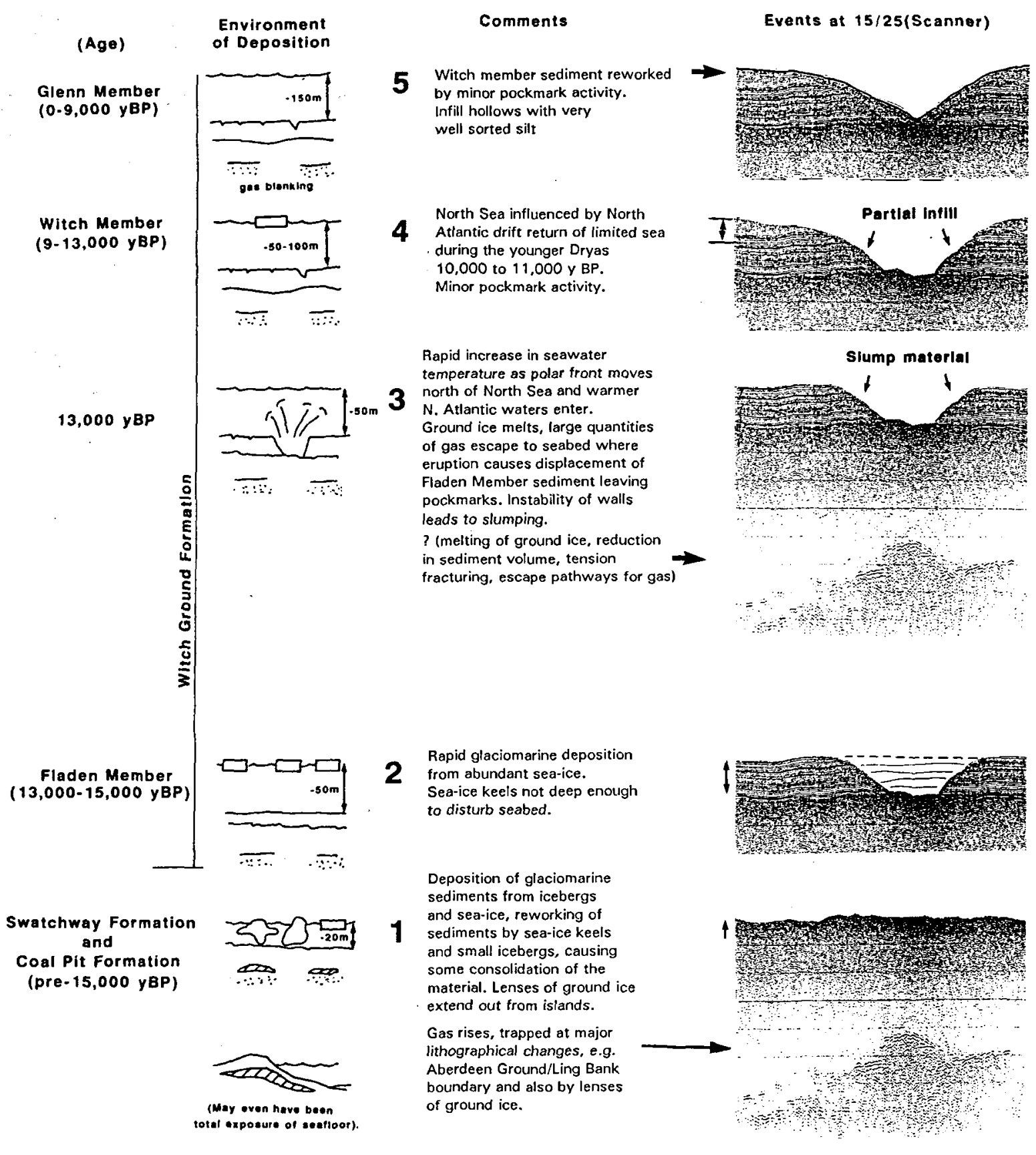

Fig. 10. The formation on the 'Scanner' pockmark. The sequence of events is illustrated by 'back-stripping' layers from the BGS digital boomer profile (Fig. 3).

by the base of the Coal Pit Formation (as indicated in Fig. 5). The distribution of gas at this interface was mapped by Geoteam in 1983 and during the Challenger cruise of 1991, see Fig. 7. It is seen on Figs 2 and 6 at about $300 \mathrm{msec}$ TWT.

2) 230-390 m: within the Aberdeen Ground Formation.
Gas at this depth was considered by Geoteam (1983) to cover virtually their entire survey area (see Fig. 8). It is indicated at approximately $500 \mathrm{msec}$ on Figs 2 and 6.

3) 960-1100 m: less extensive occurrences within this depth range were identified by Geoteam (1983). They

Judd et al.: Pockmark formation and activity 
lie within the Nordland Group (Pliocene) sediments and may represent either a lignite layer or gas trapped within a sandstone horizon.

\section{Depth of the shallowest gas}

Fig. 9 indicates variations in the depth below seabed of the shallowest gas, as interpreted from the digital boomer data acquired in 1991. The depth varies considerably from $<55 \mathrm{~m}$ to $>75 \mathrm{~m}$ below seabed. This semi-continuous accumulation of gas-charged sediments is apparently trapped at the base of the Coal Pit Formation, the topography of which determines its depth. It is not known whether or not the gas migrates laterally within the layer. Discrepancies between the extent of the gas mapped in 1983 and 1991 (shown in Fig. 7) may be indicative of lateral movement, however differences in the seismic technique and the accuracy of the positioning systems make it impossible to rely on the comparison; whilst the evidence does not conclusively demonstrate that lateral migration has occurred, neither does it conclusively indicate that the extent of the gas remains unchanged. A similar conclusion was reached by Judd (1990) who compared the results of repeat boomer surveys of the gascharged sediments around the Witch's Hole (UK block 21/4).

It is noted that the active pockmarks, most notably 'Scanner', overlie areas where the gas is relatively shallow (i.e. on topographic highs, see Fig. 9). It seems that the gas migrates laterally until it becomes trapped within these highs, then it rises vertically to escape to the seabed through the pockmarks. This may explain the location of the active pockmarks, however the location of smaller pockmarks is less easily explained. They were evidently formed more recently than the named active pockmarks as they cut into the youngest sediments. Perhaps they represent minor vertical pathways above small topographic highs.

\section{Origin of the gas}

In the Witch Ground Graben, as in the northern North Sea in general, the principal petroleum source rock is the Kimmeridge Clay. The fact that this formation is not well-represented in well 15/25b-la (see Fig. 4) does not preclude it as a source of oil and thermogenic gas. The oil or gas may have migrated into reservoir formations where suitable trap structures are present. Similarly gas from the underlying sediments (e.g. the Carboniferous coals) could be present. The drilling at the site indicates a petroleum potential for the Upper Jurassic Piper Sands (the main reservoir for several producing fields in the eastern Moray Firth, e.g. Piper, Tartan and Claymore) and the sands of the Palæocene Montrose Group (exploited at the Balmoral and Cyrus fields, for example). However, well $15 / 25$ b-1a was reported as 'dry'. This may indicate either that the potential reservoir sands never filled, or that petroleum migration has proceeded laterally or vertically beyond the well site.

Lignite horizons and lignite-bearing sands are present within the Hordaland and Nordland Group sediments of this area (Andrews et al. 1990). These lignites may well be the source of biogenically-derived gas. Information from well 15/25b-1a and bright spots seen in the deeper parts of the seismic profiles acquired at this site (and reported from elsewhere in the area by Andrews et al. 1990), indicate that gas-charged layers are present in these formations. Gas samples collected from the Scanner pockmark had a 'biogenic' carbon isotope signature $\left(\delta^{13} \mathrm{C}\right.$ $-70 \%$. PDB, Hovland \& Irwin, 1989). This suggests that the Tertiary lignites are the most likely source of the gas. It is presumed that the gas, once generated, migrates upwards and may accumulate in porous horizons where it is trapped by overlying less permeable sediments. This situation is frequently encountered in the contrasting lithologies of the Aberdeen Ground, Ling Bank, Fisher and Coal Pit Formations.

Whether the gas is of Tertiary age or older, gas generation must have commenced considerably earlier than the deposition of the Quaternary sediments in which it is now accumulated. There is no reason to suggest that gas generation has ceased in the recent geological past, consequently it can be assumed that there is a continuous supply of gas from below the Quaternary sediments.

\section{History of pockmark formation}

On the digital boomer profile of the Scanner pockmark (Fig. 3) it can be seen that the pockmark has been cut down to the top of the Coal Pit Formation (which is known from seabed sampling to be exposed). Inspection of the layering adjacent to the pockmark (see Fig. 3) shows that the older sediments of the Witch Ground Formation have been removed, but there is an infill of younger sediments. By back-stripping the various sediment units it is possible to reconstruct the history of the formation of this pockmark (it should be noted that the effects of compaction and subsidence are not taken into account; however the high moisture content and low density measured elsewhere in Witch Ground Formation sediments suggest that these effects would be small). The events described below are represented on fig. 10 by the appropriate event numbers (the environmental conditions were described in greater detail above):

Event 1 Deposition of the sediments of the Coal Pit Formation; scouring and compaction of the top of the Coal Pit Formation by ice [before 15,000 BP in approximately $20 \mathrm{~m}$ of water];

Event 2 Deposition of the lower parts of the Witch Ground Formation (Fladen Member) [between 15,000 and $13,000 \mathrm{BP}$ in approximately $50 \mathrm{~m}$ of water];

Bulletin of the Geological Society of Denmark 
Event 3 Main pockmark formation event; existing Witch Ground Formation sediments removed to expose the Coal Pit Formation [approximately $13,000 \mathrm{BP}$ in about $50 \mathrm{~m}$ water]; slumping of the pockmark walls, probably immediately after pockmark formation;

Event 4 Deposition of the later Witch Member of the Witch Ground Formation [post 13,000 BP].

Event 5 Deposition of the Glen Member of the Witch Ground Formation [Holocene - post-10,000 BP]

Evidently, prior to the deposition of the later Witch Ground Formation sediments the pockmark was considerably larger than it is at present, although it was no deeper; the stiff Coal Pit Formation sediments proved too resistant to be eroded. It is estimated that the feature, which currently has a volume of approximately $0.7 \times 10^{6}$ $\mathrm{m}^{3}$, was previously about $30 \%$ larger. Although it cannot be certain that pockmark formation did not commence prior to the deposition of the Fladen Member, it certainly was completed before the deposition of the later Witch Member. The pockmark-forming event must therefore have occurred during a relatively short time period, probably between 15,000 and 13,000 years BP. Since the pockmark was formed it has been partially infilled, firstly by slumped side-wall material, and then by sedimentation, and any gas escape since then has been insufficiently vigorous to prevent net infilling. Profiles across the Challenger pockmark indicate a similar formation history and timescale.

\section{Otolith concentration}

Dando et al. (1991) found that in the Scanner pockmark there is an unusually large proportion of fish otoliths in the seabed sediments: $1,550 \mathrm{~m}^{-2}$ on average, compared to $2 \mathrm{~m}^{-2}$ found in equivalent sediments outside the pockmark. This concentration might be explained by the winnowing of the large volume of sediments missing from the site. This assumes that the seabed sample is about 2 $\mathrm{cm}$ thick, hence a background concentration of 2 otoliths $\mathrm{m}^{-2}$ is equivalent to $100 \mathrm{~m}^{-3}$. Assuming that all otoliths settled back into the pockmark when the sediment was removed, and that $17 \mathrm{~m}$ of sediment was ejected, a concentration of about $1,700 \mathrm{~m}^{-2}$ would result. This is similar to that reported (Dando et al. 1991). However, if at the time of the pockmark-forming event, the thickness of erodable sediment (above the Coal Pit Formation) was less then $17 \mathrm{~m}$, or if some of the otoliths were transported away from the pockmark, the concentration would have been less. Also fluctuations in the concentration of otoliths might be expected through the sedimentary pile.

There has been virtually no sediment input since about 8,000 years ago (see above), so, on the basis of time, a concentration of no more than $5 \mathrm{~m}^{-2}$ could be expected for a late glacial maximum surface, assuming that the otolith production rate has remained constant since about 18,000 BP. There is such a significant discrepancy in otolith concentration between the pockmark floor $(1,500$ $\left.\mathrm{m}^{-2}\right)$ and outwith the pockmark $\left(2 \mathrm{~m}^{-2}\right)$ that a biological concentrating factor seems most likely, rather than it being the result of the pockmark forming process. It is suggested that an abundance of fish has been attracted to the site (as has been suggested by Hovland and Judd, 1988), and hence the increased otolith deposition rate.

\section{Discussion}

The formation of pockmarks by fluid (mainly gas) escape is now generally accepted. Hovland \& Judd (1988) described a process whereby gas migrating towards the seabed would accumulate in reservoirs at successively higher levels, eventually escaping from each one in turn once a migration pathway had been established. Escape from the topmost reservoir would allow the gas to escape through the seabed, forming a pockmark (if the seabed sediments are of a suitable composition and strength). Once a migration pathway has been established, Hovland \& Judd surmised that it might be kept open by continual use. Their conclusion that pockmark formation might be initiated by a catastrophic gas escape event is supported rather than denied by the evidence presented here. Evidence described in this paper suggests that the Scamer pockmark formed by one (or possibly more) vigorous or even catastrophic gas escape events approximately 13,000 years ago. This hypothesis, based upon the sequence of sediments revealed in the pockmark by the digital boomer data, is supported by the conclusions of Long (1992). Long recognised a significant increase in the frequency of buried pockmarks at the Fladen/Witch Member boundary within the Witch Ground Formation. One possible explanation, that this horizon (like the present seabed) represents a long time period during which negligible deposition occurred, is not upheld by the chronological evidence. It is more likely that gas release and pockmark formation activity peaked when warm North Atlantic waters entered the North Sea, causing a rapid rise in bottom water temperatures, the melting of subsurface lenses of ground ice and the release of shallow gas trapped beneath these lenses.

If the gas escape events described here and by Long are indicative of a period of increased gas escape, they may represent significant contributions to atmospheric methane concentrations. They may constitute positive feedback, contributing to an acceleration of the warming of the global atmosphere and the return to inter-glacial conditions (as suggested by Nisbett (1990).

Since the formation of the pockmarks, it would seem that the gas migration pathway has been utilised to allow further seepage activity. Gas plumes have been observed on each of the occasions when the Scanner pockmark has been visited: 1983, 1985, 1988, 1989 (July and August), 1990 \& 1991. From visual observation made by ROV 
(Remotely Operated Vehicle) in 1985 (Hovland and Judd, 1988) and by manned submersible in 1990 (P. R. Dando Pers. Comm.) it has been reported that the gas seeps consist of continuous or intermittent streams of small (< $40 \mathrm{~mm}$. diameter) bubbles emanating from a number of discrete vents on the pockmark floor. Apparently these emanations are not sufficiently vigorous to erode the Coal Pit Formation sediments through which they are escaping.

The fact that the pockmarks described in this paper were formed long ago, at a time of peak gas escape activity does not imply that new pockmarks have not formed since. Indeed there is ample evidence to suggest that most pockmarks were formed since the deposition of the majority of the Witch Ground Formation. To the left of the 'Challenger' pockmark on fig. 5 , an example can be seen; the base of this relatively shallow pockmark is cut only to within a few metres of the present seabed, and a gas migration pathway can be seen vertically beneath it. It would seem that this feature formed relatively recently, possibly within historical times. There is no reason to suppose that the mode of formation of this pockmark was any different to that of the Scanner pockmark, although from its size it would seem that the gas escape event which initiated it was considerably less catastrophic.

There is no incontravertable evidence that very shallow gas migrates laterally as comparisons between repeat surveys are unreliable. However the existence of active pockmarks above topographic highs in the capping sediment suggests that gas is channelled laterally towards the escape route. As lateral migration cannot be ruled it is worthy of note that delimitations of the extent of shallow gas during site surveys may not be valid over extended time periods.

The conclusions that pockmarks may have formed by a catastrophic gas escape event, that gas is still migrating from depth, and that pockmarks have formed in the recent past, may be of particular interest to the oil industry. Any such event occurring at the present day could represent a considerable hazard to offshore installations. Indeed Green, Heijna \& Walker (1985) suggested that the determination of the 'return period' of gas escape events would enable the true hazard potential to be assessed.

\section{Acknowledgments}

The authors acknowledge many people for the acquisition, processing and provision of the data on which this paper is based. Conoco U.K. Ltd. kindly gave permission for the use of the 1983 site survey data (produced by Geoteam (U.K. Ltd.), the composite log (made available by Chris Clayton of B.P. Research Ltd.) and the 1991 data (produced by Marconi UDI Ltd.). The attribute analyses were performed by Lynette Pritchard, a (former) student at the University of Sunderland, whilst she was on placement with Marconi UDI Ltd. Paul Dando (Marine Biological Society of Great Britain) was the Chief Scientist on the two 'Challenger' cruises (1990 and 1991) and the digital boomer data was acquired by Nigel Fannin (1990), Colin Brett (1990 and 1991) and Dave Smith (1990 and 1991). Will Dempster contributed to the back-stripping exercise whilst he was a student at the University of Sunderland. The diagrams were prepared by Neil Purvis and Pat Cowell. We thank Gordon Fader for his constructive criticism of the manuscript. DL and MS publish with the permission of the Director of the British Geological Survey.

\section{Dansk sammendrag}

Seismisk kortlægning af 3 aktive pockmarks i UK blok $15 / 25$ i den britiske del af Nordsøen lader formode, at disse gasrelaterede morfologiske strukturer blev dannet allerede før de senest aflejrede postglaciale marine sedimenter $\mathbf{i}$ området. Pockmarks formodes at dannes under pludselige gasudslip i havbunden, og en mulig årsag kan i dette tilfælde være bortsmeltningen af den sidste is $i$ nordsøområdet for ca. 13.000 år siden. Efter deres dannelse er de stadig aktive pockmarks blevet delvist opfyldt på grund af slumpingprocesser langs siderne og af postglacial marin sedimentation i de centrale dele.

De geologiske informationer fra nærliggende olieboringer tyder på, at en mulig kilde til den overfladenære gas er dybereliggende Kimmeridge Clay eller evt. lignitholdige Tertiære sedimenter. Der er indtil flere impermeable horisonter i den Tertiære/Kvarære lagserie, som kan give ophav til akkumulering af den optrængende gas, hvoraf den yngste, Coal Pit Formationen, befinder sig mindre end 80 meter under havbunden i det unders $\varnothing g t e$ område. De seismiske data tyder på, at basistopografien af Coal Pit Formationen i stor udstrækning kontrollerer den videre migration af gas mod havbunden, $o g$ at migrationsvejen for gassen til de stadig aktive pockmarks har været relativ konstant fra dannelsestidspunktet indtil i dag.

\section{References}

Andrews, I. J., Long, D., Richards, P. C., Thomson, A. R. Brown, S., Chesher, J. A. \& McCormac, M. 1990: The Geology of the Moray Firth. United Kingdom Offshore Regional Report, British Geological Survey.

Dando, P. R., Austen, M. C., Burke R. J. jnr., Kendall, M. A., Kennicutt, M. C. II, Judd, A. G., Moore, D. C., O'Hara, S. C. M., Schmaljohann, R. \& Southward, A. J. 1991: Ecology of a North Sea pockmark with an active methane seep. Marine Ecology Progress Series, 70, 49-63.

Erlenkeuser, H. 1979: Environmental effects on radiocarbon in coastal marine sediments. In Berger, R. \& Suess, H. E. (Eds.) Radiocarbon Dating. Proc. 9th Internat. Conf., Los Angeles and La Jolla, Univ. of California Press, 453-469.

Geoteam, 1983 Site Survey, location 15/25b-A. Confidential report to Conoco U.K. Ltd.

Bulletin of the Geological Society of Denmark 
Green, C. D., Heijna, B. \& Walker, P. 1985: An integrated approach to the investigation of new development areas. In Advances in Underwater Technology and Offshore Engineering, Vol. 3. Offshore Site Investigation, Graham and Trotman, London.

Hovland, M. \& Irwin, H. 1989: Habitat of methanogenic carbonate cemented sediments in the North Sea. In Proc. 'Bacterial Methane' Conference, Milan, Italy.

Hovland, M. \& Judd, A. G. 1988: Seabed pockmarks and seepages: impact on geology, biology and the marine environment. Graham \& Trotman, London, 293 pp.

Hovland, M. \& Sommerville, J. H. 1985: Characteristics of two natural gas seepages in the North Sea. Marine \& Petroleum Geol. 20, 319-326.

Johnson, T. C. \& Elkins, S. R. 1979: Holocene deposits of the northern North Sea: evidence for dynamic control of their mineral and chemical composition. Geologie en Mijnbouw $58,353-366$

Judd, A. G. 1990: Shallow gas and gas seepages: a dynamic process? In Ardus D. A. \& Green C. D. (Eds) Safety in Offshore Drilling: the role of shallow gas surveys. Kluwer Academic, 27-50.

Long, D. 1986: Seabed sediments, Fladen Sheet $58^{\circ} \mathrm{N}-00^{\circ}$. 1:250,000 map series, British Geological Survey.
Long, D. 1992: Devensian Late-glacial gas escape in the central North Sea. Continental Shelf Research 12, 1097-1110.

Long, D., Bent, A., Harland, R., Gregory, D. M., Graham, D. K., \& Morton, A. C. 1986: Late Quaternary palaeontology, sedimentology and geochemistry of a vibrocore from the Witch Ground Basin, central North Sea. Marine Geology 73, 109123.

Marconi UDI Ltd. 1991: Test Data: UKCS block 15/25b. Confidential Report to Conoco U.K. Ltd.

Nisbett, E. 1990: The end of the Ice Age. Can. J. Earth Sci. 27, 148-157.

Stoker, M. S. \& Bent, A. J. A. 1987: Lower Pleistocene deltaic and marine sediments in boreholes from the central North Sea. J. Quaternary Geology 2, 87-96.

Stoker, M. S. \& Long, D. 1984: A relict ice-scoured erosion surface in the central North Sea. Marine Geology 61, 85-93.

Stoker, M. S., Long, D. and Fyfe, J. A. 1985: A revised Quaternary stratigraphy for the central North Sea. Report of the British Geological Survey 17(2).

Walker, P. M. 1990: UKOOA recommended procedures for mobile drilling rig site surveys (geophysical and hydrographic) - shallow gas aspects. In Ardus D. A. \& Green C. D. (Eds) Safety in Offshore Drilling: the role of shallow gas surveys. Kluwer Academic, 257-289. 